\title{
Protein Status in Cattle raised in the Wetlands of Paraguay during three periods of the year
}

\author{
Estatus proteico en Bovinos criados en los Humedales de Paraguay \\ durante tres periodos del año
}

\author{
Roberto Martínez-López ${ }^{1,3 *}$ (D) , Liz Mariela Centurión-Insaurralde ${ }^{2}$ (D), Olga Lorena Núñez-Yegros ${ }^{3}$ (D) and \\ Dan Phillip Sponenberg ${ }^{4}$
}

\begin{abstract}
${ }^{1}$ Centro Multidisciplinario de Investigaciones Tecnológicas, Universidad Nacional de Asunción. San Lorenzo, Paraguay, ${ }^{2}$ Facultad de Ciencias Exactas y Naturales, Universidad Nacional de Asunción. San Lorenzo, Paraguay, ${ }^{3}$ Facultad de Ciencias Veterinarias, Universidad Nacional de Asunción. San Lorenzo, Paraguay, " Virginia - Maryland College of Veterinary Medicine. Blacksburg, Virginia, USA.
\end{abstract}

Email: robertomartinezlo@vet.una.py

\begin{abstract}
Livestock activities, mainly those related to livestock rearing, are generally carried out in special and specific environments, susceptible to alterations, with particular and inherent characteristics of soil, vegetation and climate, not conducive to the development of the farming. Paraguay is no exception, because more than half of its territory is made up of semi-arid and wetlands, one of the most representative being the Ñeembucú wetlands and its areas of influence. In this area, the presence of certain genetic groups made up of local or naturalized bovines and bovines of transnational or exotic genetics stands out. The aim of this work was to assess protein status in cattle during the summer, fall, and winter as an indicator of adaptation to the wetlands of Ñeembucú, Paraguay. The study compared local and exotic breeds in an extensive cattle farming system, grouped by genotype into Criollo Ñeembucú; Criollo Pilcomayo; Nelore; Brangus, and Brahman. Blood levels of urea, creatinine, total protein, albumin, globulin, albumin/globulin ratio, and body condition were analyzed. The local criollo breeds had higher urea concentrations, total protein, and globulin values, most markedly in the summer. The exotic breeds had elevated creatinine levels. Nelore had the lowest marks for body condition both in the summer and winter. The analysis of main components explained over $60 \%$ of the variation. Globulin and total protein integrated the first component in all three seasons. The most dissimilar breed pairs were Criollo Ñeembucú and Brahman, and also Criollo Pilcomayo and Nelore. The results suggest an adaptation process in the metabolic pathways of nitrogenated compounds and the potential capacity for immune response in local breeds. The results suggest that exotic breeds have mechanisms that compromise tissue protein integrity and renal function in the specific environments particular to the wetlands of Ñeembucú.
\end{abstract}

Key words: Adaptation; genotype-environment interaction; humid tropic; local breeds; metabolic profile

\section{RESUMEN}

Las actividades pecuarias, principalmente las relacionadas a la cría de ganado, se llevan a cabo generalmente en ambientes especiales y específicos, susceptibles a alteraciones, con características de suelo, vegetación y clima particulares e inherentes a los mismos, no propicias para el desarrollo de la agricultura. Paraguay no es la excepción, debido a que más de la mitad de su territorio está constituido por semiáridos y humedales, siendo uno de los más representativos, los humedales del Ñeembucú y sus áreas de influencia. En esta zona, se destaca la presencia de ciertos grupos genéticos constituidos por bovinos locales o naturalizados y bovinos de genética transnacional o exótica. El objetivo de este trabajo fue evaluar el estado de las proteínas en el ganado durante el verano, otoño e invierno como un indicador de adaptación a los humedales de Ñeembucú, Paraguay. El estudio comparó razas locales y exóticas en un extenso sistema de cría de ganado, agrupadas por genotipo en Criollo Ñeembucú; Criollo Pilcomayo; Nelore Brangus y Brahman. Se analizaron los niveles sanguíneos de urea, creatinina, proteína total, albúmina, globulina, proporción de albúmina / globulina y condición corporal. Las razas criollas locales tenían mayores concentraciones de urea, proteínas totales y valores de globulina, más notablemente en el verano. Las razas exóticas tenían niveles elevados de creatinina. Nelore tuvo las notas más bajas para la condición corporal, tanto en verano como en invierno. El análisis de los componentes principales explicó más del $60 \%$ de la variación. La globulina y la proteína total integraron el primer componente en las tres estaciones. Las parejas de razas más diferentes fueron Criollo Ñeembucú y Brahman, y también Criollo Pilcomayo y Nelore. Los resultados sugieren un proceso de adaptación en las vías metabólicas de los compuestos nitrogenados y la capacidad potencial de respuesta inmune en las razas locales. Los resultados sugieren que las razas exóticas tienen mecanismos que comprometen la integridad de la proteína del tejido y la función renal en los entornos específicos particulares de los humedales de Ñeembucú.

Palabras clave: Adaptación; interacción genotipo-ambiente; trópico húmedo; razas locales; perfil metabólico 


\section{INTRODUCTION}

The sustainability of agroecological systems depends upon the adaptation of their components. In relation to animals, genotypeenvironment interaction constitutes the main platform for the process of adaptation and natural selection of individuals with the necessary metabolic capacity for efficient performance in terms of production and reproduction, especially in less favored environments [6]. In that context, animals have developed mechanisms to maintain either a state of balance (homeostasis) or reorientation (homeorhesis) [17].

The molecular bases of cattle adaptation to tropical conditions have been postulated in relation to processes linked to immunity, metabolic pathways, and heat tolerance [23]. It is important to consider that activities related to livestock production are carried out in specific environments that have specific and inherent soil, vegetation, and weather characteristics and are usually unfit for crop cultivation. In this scenario, Paraguay is no exception. Its territory is constituted by both semi-arid regions and wetlands. The Ñeembucú region is the most typical wetland, along with adjacent areas that are influenced by it. In this region, the presence of certain genetic groups of cattle (Bos indicus and Bos taurus) is noteworthy.

One group consists of local and long-term naturalized cattle represented by the Criollo Pilcomayo and Criollo Ñeembucú breeds, where natural barriers have favored processes of adaptation and natural selection by prolonged exposure to specific environments [15]. Cattle breeds with more recently introduced foreign or exotic genetics are raised in this same region and under similar management systems. These introduced breeds are traditionally employed in these production systems (PS) in response to livestock production expectations that are not based on scientific results. The aim of this study was to assess the protein metabolic status of local and exotic cattle breeds maintained in an extensive farming system as an indicator of adaptation to a single environment (the wetlands of Ñeembucú and surrounding areas) during three periods of the year (yr): summer, fall, and winter.

\section{MATERIALS AND METHODS}

The study was carried out in cattle farms located in the Ñeembucú wetlands and areas of influence, in the specific sites they included places called Isla Umbú (south latitude (SL)-27.0871860, west longitude (WL)-58.4148570, altitude 52 meters above sea level, - masl-); Nueva Italia (SL-25.5138530, WL-57.4756850, altitude 113 masl); San Miguel (SL-26.6252670, WL-57.0502620, altitude 113 masl); Caapucú (SL-26.2750150, WL-57.1643630, altitude 65 masl). All of them located in the southern zone of Eastern Region of Paraguay, in the Humid Chaco ecoregion [2]. The corresponding Thornthwaite climate classification is Subhumid-humid, Megathermal, with average rainfall between $1400-1600$ milimeters $(\mathrm{mm}) \cdot \mathrm{yr}^{-1}$.

The study assessed cows adult, between 4 and 5 yr old (identified by fire on the haunch), with an average weight of $350 \pm 40$ kilograms $(\mathrm{kg})$. The management system was of the extensive type that in characteristic terms of the area, which strictly includes direct grazing in fenced pasture schemes with periodic rotations according to the availability of forage, supported by grasses (mainly: Paspalum spp., Cynodon spp., and Brachiaria spp.) and with mineralized supplementation. As for the health plan, it only includes the standard that governs the Country, with preventive vaccinations. No hormones, stimulants, balanced rations or biological additives of any kind are used.
They were selected without apparent metabolic disorders, 16 cows for each of the 5 genotype. Three of them corresponded to imported or exotic breeds, Brahman, Nelore and Brangus, these were included because they are traditionally used by all producers in the area and according to the public and personal communications of all, they are the ones that best adapt in the place, for calf production. Likewise, two bovine genetic groups called criollos were considered, the Ñeembucú and the Pilcomayo, both at risk of extinction and frank degradation (with an effective population size, below 120 heads), as they are the last remnants of criollos naturally existing in the wetland and its area of influence. In the place there are no other cattle genotypes bred extensively or semi-extensively, as far as production for meat is concerned.

A randomized block design was used, where the "farm" effect was statistically neutralized. The four establishments are under the same edaphoclimatic and agroecological conditions of the wetlands and their area of influence (basin), according to the international conformation of the Ramsar list [7, 24], which includes the Ñeembucú wetlands. Therefore, they are similar management conditions, breeding system, health and nutritional plan. The assessments were carried out at the end of the summer, fall, and winter, at intervals of 90 days (d), during the month (mon) of March, June, and September of 2017. The groups included more animals than necessary for the assessment of a metabolic profile [28]. The sampling was non-probabilistic for convenience.

For the procedure, the cattle were at rest and with a minimum fast of six hours (h). They were led to the pen and onto the containment ramp to assess body condition scores on a scale of 1 to 5 [8]. All the selected ones presented body condition equal to 3.4 to 4.0. Physiological parameters were evaluated to determine the general health status based on the ranges considered normal for cattle and based on the type of animal, age and physiological status. Animals used for the study were identified by numbered tags applied to the left outer ear (caravan).

Ten mililiters $(\mathrm{mL})$ of blood were extracted through venipuncture of the coccygeal vein, $5 \mathrm{~mL}$ of which were deposited in a heparinized tube, and the remaining $5 \mathrm{~mL}$ in a sterile tube without anticoagulant to harvest serum by centrifugation (brand: Cencom II, maker: Selecta S.A., Spain, 1.540 G). Once obtained, the serum was deposited in $2 \mathrm{~mL}$ Eppendorf tubes. All samples were identified and refrigerated in dry ice until they were sent to the laboratory.

Biochemical factors that were analyzed in order to determine the balance of the nitrogenated compounds were: urea (micromol $\left(\mathrm{mmol} \cdot \mathrm{L}^{-1}\right)$ ); creatinine $\left(\mu \mathrm{mol} \cdot \mathrm{L}^{-1}\right)$; total protein (grames $\left.(\mathrm{g}) \cdot \mathrm{L}^{-1}\right)$; albumin $\left(\mathrm{g} \cdot \mathrm{L}^{-1}\right)$; globulin $\left(\mathrm{g} \cdot \mathrm{L}^{-1}\right)$. The analysis was carried out through the CB 350i chemical auto analyzer from Wiener lab ${ }^{\circledR}$, with specific reagents from the manufacturer. The kinetic ultraviolet (UV) urea assay (AA kit) and the enzymatic urease / glutamate dehydrogenase (GLDH) technique were used for the determination of urea levels; the kinetic Jaffé method (AA kit) and the Jaffé alkaline picrate method were used for creatinine; and the colorimetric method (AA kit), the Biuret test, and Bromocresol green for total protein and albumin. The value of the globulin fraction was obtained by calculating the difference between total protein and albumin fraction. For the interpretation of the results, the method of direct comparison was used based on the reference interval published by Wittwer [27].

The data were analyzed with the $\mathrm{R}$ - project statistical software [22] to verify the theoretical distribution observations of the obtained 
observations with the Shapiro-Wilk test [14], applying analysis of variance and the Tukey test [14] for the comparison of means between genotypes for the variables that followed a parametric distribution during the summer (urea, creatinine, total protein, globulin, albumin/globulin ratio), fall (creatinine, total protein, globulin, albumin, albumin/globulin ratio, body condition) and winter (urea, total protein, globulin).

The Kruskal-Wallis test and the Dunn contrast were employed for the analysis of the variables with a non-parametric distribution during the summer (albumin and body condition), fall (urea) and winter (creatinine, albumin, albumin/globulin ratio and body condition) [14]. The same criterion was used for the comparison of means per season, according to the behavior of the data within each genetic group. The variation of nitrogen compounds in the different genotypes was analyzed at through principal component analysis [25].
It is recalled that the main objective of the work was to verify and analyze the protein status in the traditional area of calf rearing in Paraguay, comparing the three cattle breeds for meat typically used in the place, and the last two traces of Creole cows existing in the region, in a situation of imminent risk of extinction.

\section{RESULTS AND DISCUSSION}

The mean values of the nitrogenated compounds in the three periods evaluated were shown in TABLE I and TABLE II.

During the summer, the genotype with the highest mean values for urea, statistically different $(P<0.05)$ from the other assessed groups, was Criollo Ñeembucú $\left(\mathrm{mmol} \cdot \mathrm{L}^{-1}\right)$; while during the fall it was joined by Nelore and Criollo Pilcomayo, which showed higher concentrations $\left(5.13 \mathrm{mmol} \cdot \mathrm{L}^{-1} ; 4.90 \mathrm{mmol} \cdot \mathrm{L}^{-1}\right.$ and $4.62 \mathrm{mmol} \cdot \mathrm{L}^{-1}$,

TABLE I

Comparison of Means of Hematological Indicators related to Protein Balance and Body Condition, assessed between Genotypes

\begin{tabular}{|c|c|c|c|c|c|c|c|c|c|c|c|}
\hline \multirow{3}{*}{ Season } & \multirow{3}{*}{ Variables } & \multicolumn{10}{|c|}{ Genotypes } \\
\hline & & \multicolumn{2}{|c|}{ Criollo Ñeembucú } & \multicolumn{2}{|c|}{ Criollo Pilcomayo } & \multicolumn{2}{|c|}{ Brangus } & \multicolumn{2}{|c|}{ Brahman } & \multicolumn{2}{|c|}{ Nelore } \\
\hline & & $\overline{\mathbf{x}}$ & SD & $\overline{\mathbf{x}}$ & SD & $\overline{\mathbf{x}}$ & SD & $\overline{\mathbf{x}}$ & SD & $\overline{\mathbf{x}}$ & SD \\
\hline \multirow{7}{*}{ Summer } & Urea $\left(\mathrm{mmol} \cdot \mathrm{L}^{-1}\right)$ & $7.51 \mathrm{~b}$ & 1.44 & $4.91 a$ & 1.45 & $4.10 \mathrm{a}$ & 1.26 & $5.03 a$ & 0.78 & $5.10 a$ & 0.50 \\
\hline & Creatinine $\left(\mu \mathrm{mol} \cdot \mathrm{L}^{-1}\right)$ & $110 a$ & 24.58 & $94.4 a$ & 7.45 & $143 b c$ & 20.75 & $131 b$ & 17.99 & $160 c$ & 17.80 \\
\hline & Total protein $\left(\mathrm{g} \cdot \mathrm{L}^{-1}\right)$ & $86.6 b$ & 8.40 & $85.9 b$ & 4.33 & $85.0 \mathrm{~b}$ & 7.97 & $82.1 \mathrm{ab}$ & 4.30 & $78.8 \mathrm{a}$ & 2.41 \\
\hline & Albumin $\left(\mathrm{g} \cdot \mathrm{L}^{-1}\right)$ & $41.1 b$ & 2.66 & $40.7 b$ & 1.25 & $43.3 b c$ & 4.82 & $44.4 \mathrm{c}$ & 3.14 & $38.1 a$ & 1.36 \\
\hline & Globulin $\left(g \cdot \mathrm{L}^{-1}\right)$ & $45.4 \mathrm{~b}$ & 8.46 & $45.1 \mathrm{~b}$ & 4.27 & $41.5 a b$ & 7.70 & $37.8 a$ & 4.34 & $40.5 a b$ & 3.01 \\
\hline & Albumin/Globulin & $0.94 a$ & 0.20 & $0.91 a$ & 0.10 & $1.08 a b$ & 0.25 & $1.19 \mathrm{~b}$ & 0.19 & $0.95 a$ & 0.09 \\
\hline & Body condition & $3.91 b$ & 0.33 & $4.03 a b$ & 0.34 & $4.28 a$ & 0.26 & $4.19 a b$ & 0.54 & $3.16 c$ & 0.54 \\
\hline \multirow{7}{*}{ Fall } & Urea $\left(\mathrm{mmol} \cdot \mathrm{L}^{-1}\right)$ & $5.13 b$ & 1.11 & $4.62 b$ & 0.76 & $3.13 a$ & 0.90 & $3.02 \mathrm{a}$ & 0.64 & $4.90 \mathrm{~b}$ & 0.86 \\
\hline & Creatinine $\left(\mu \mathrm{mol} \cdot \mathrm{L}^{-1}\right)$ & $120 a$ & 15.09 & $108 a$ & 15.34 & $144 b$ & 22.50 & $118 a$ & 15.10 & $162 c$ & 16.41 \\
\hline & Total protein $\left(\mathrm{g} \cdot \mathrm{L}^{-1}\right)$ & $76.8 a$ & 4.64 & $83.3 b$ & 4.64 & $77.6 a$ & 5.69 & $74.7 a$ & 6.19 & $75.3 a$ & 4.96 \\
\hline & Albumin $\left(\mathrm{g} \cdot \mathrm{L}^{-1}\right)$ & $45.8 \mathrm{c}$ & 2.46 & $39.4 a$ & 2.22 & $41.2 \mathrm{ab}$ & 2.29 & $40.3 a$ & 1.99 & $43.2 b$ & 1.64 \\
\hline & Globulin $\left(\mathrm{g} \cdot \mathrm{L}^{-1}\right)$ & $31.1 \mathrm{a}$ & 4.65 & $43.9 \mathrm{c}$ & 4.44 & $36.4 b$ & 5.11 & $34.3 a b$ & 6.18 & $32.4 a b$ & 4.72 \\
\hline & Albumin/Globulin & $1.51 \mathrm{~d}$ & 0.27 & $0.91 a$ & 0.11 & $1.15 b$ & 0.16 & $1.21 \mathrm{bc}$ & 0.22 & $1.36 \mathrm{~cd}$ & 0.20 \\
\hline & Body condition & $4.28 \mathrm{~b}$ & 0.93 & $3.47 a$ & 0.83 & $4.00 \mathrm{ab}$ & 0.68 & $3.84 a b$ & 0.65 & $3.88 a b$ & 0.62 \\
\hline \multirow{7}{*}{ Winter } & Urea $\left(\mathrm{mmol} \cdot \mathrm{L}^{-1}\right)$ & $5.71 d$ & 0.98 & $4.62 b c$ & 1.28 & $3.28 \mathrm{a}$ & 0.86 & $3.91 \mathrm{ab}$ & 0.51 & $5.11 \mathrm{~cd}$ & 1.03 \\
\hline & Creatinine $\left(\mu \mathrm{mol} \cdot \mathrm{L}^{-1}\right)$ & $174 b$ & 23.87 & $120 a$ & 16.13 & $203 c d$ & 19.93 & $187 b c$ & 18.00 & $214 d$ & 23.17 \\
\hline & Total protein $\left(\mathrm{g} \cdot \mathrm{L}^{-1}\right)$ & $84.7 b$ & 5.57 & $82.5 a b$ & 5.29 & $81.8 a b$ & 4.29 & $78.3 a$ & 4.13 & $80.1 \mathrm{ab}$ & 3.94 \\
\hline & Albumin $\left(g \cdot \mathrm{L}^{-1}\right)$ & 43.0ab & 1.93 & 43.3ab & 2.15 & $43.6 \mathrm{~b}$ & 2.50 & $44.0 \mathrm{~b}$ & 1.83 & $41.7 a$ & 2.15 \\
\hline & Globulin $\left(g \cdot \mathrm{L}^{-1}\right)$ & $41.8 \mathrm{~b}$ & 5.30 & $39.1 \mathrm{ab}$ & 5.98 & $38.1 \mathrm{ab}$ & 4.89 & $34.4 a$ & 3.93 & $38.3 a b$ & 3.34 \\
\hline & Albumin/Globulin & $1.05 \mathrm{c}$ & 0.14 & $1.14 \mathrm{bc}$ & 0.23 & $1.16 a b$ & 0.18 & $1.29 a$ & 0.17 & $1.09 \mathrm{bc}$ & 0.11 \\
\hline & Body condition & $3.25 a$ & 0.77 & $3.25 a$ & 0.73 & $3.13 a$ & 0.53 & $3.22 \mathrm{a}$ & 0.48 & $2.56 \mathrm{~b}$ & 0.48 \\
\hline
\end{tabular}

$\mathrm{mmol} \cdot \mathrm{L}^{-1}$ : millimole per liter; $\mu \cdot \mathrm{L}^{-1}:$ micromole per liter; $\mathrm{g} \cdot \mathrm{L}^{-1}$ : gram per liter; $\overline{\mathrm{X}}$ : Mean; SD: Standard deviation; abcd Means in the same row with different superscripts differ according to the Tukey test and the Dunn contrast $(P<0.05)$ 
Protein Status in Cattle raised in the Wetlands of Paraguay / Martínez-López et al.

TABLE II

Comparison of Means of Hematological Indicators Related to Protein Balance and Body Condition, assessed between Seasons

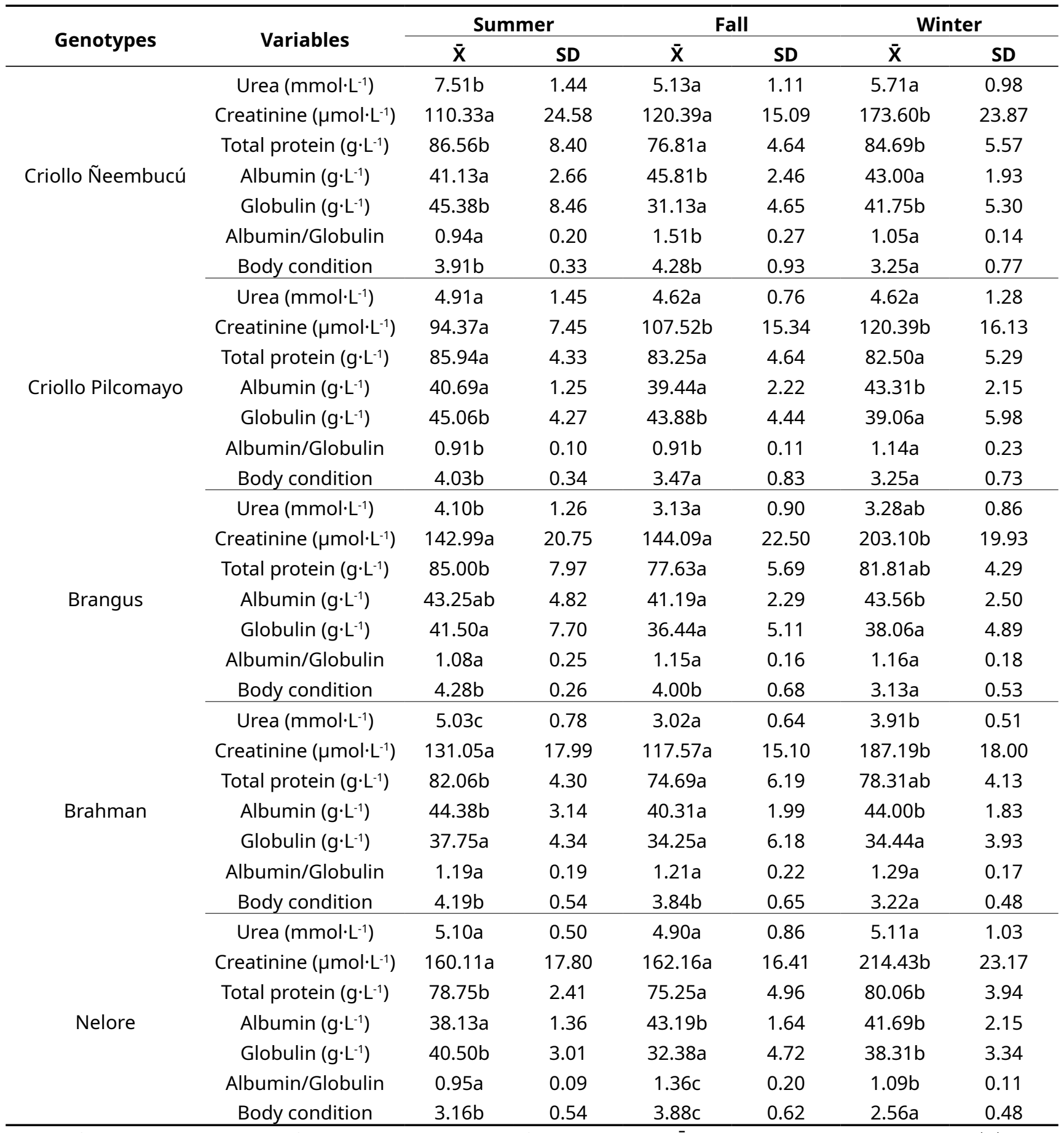

$\mathrm{mmol} \cdot \mathrm{L}^{-1}$ : millimole per liter; $\mu \cdot \mathrm{L}^{-1}$ : micromole per liter; $\mathrm{g} \cdot \mathrm{L}^{-1}$ : gram per liter; $\overline{\mathrm{X}}$ : Mean; SD: Standard deviation; abcdMeans in the same row with different superscripts differ according to the Tukey test and the Dunn contrast $(P<0.05)$

respectively). During the winter, the differences between Criollo Ñeembucú (5.71 mmol. $\mathrm{L}^{-1}$ ) and the other genotypes were marked, except against Nelore $\left(5.11 \mathrm{mmol} \cdot \mathrm{L}^{-1}\right)$. Urea concentration in blood is a short-term indicator of protein status, and it is essential to interpret it adequately through the use of reference values. 
In that sense, the difficulty of having appropriate reference values and the lack of uniformity in the criteria for their development is documented [10, 28]. In the same line of thought, Wittwer [27] mentioned direct comparison as one of the methods used in the clinical interpretation of laboratory tests. Following this principle, the urea concentrations obtained in this study for the different groups in the three evaluation periods were within the range indicated by said author $\left(2.6 \mathrm{mmol} \cdot \mathrm{L}^{-1}-7.0 \mathrm{mmol} \cdot \mathrm{L}^{-1}\right)$, except for Criollo Ñeembucú during the summer. This behavior coincides with what was reported by Campos et al. [3] when assessing Colombian local breed cows raised in the tropics, with a mean value of $10.44 \mathrm{mmol} \cdot \mathrm{L}^{-1}$, together with important levels of hypoglycemia.

The excess of ammonium transformed into urea can affect metabolic and reproductive functions by altering the levels of progesterone and uterine $\mathrm{pH}$. Peixoto et al. [20] analyzed the protein profile in cattle for meat production from different genotypes and reported higher tolerance to uremia without repercussion on conception rates, with levels of $6.73 \mathrm{mmol} \cdot \mathrm{L}^{-1}$; a value close to the ones registered in the local breeds in this research.

Another aspect to consider is the fact that the urea concentration is subject to seasonal variations associated with the energy and protein content of the grasses. It is also affected by the physiological state of the animals and the decrease of water intake, being higher in non-lactating cows, in cows that bear imbalances in the energy/ protein ratio with excess protein input or energy deficiency, and in dehydrated animals $[3,10,18,29]$.

Considering the seasonal fluctuations, higher concentrations were observed in Criollo Ñeembucú and Brahman during summertime, compared to fall and winter; while Criollo Pilcomayo and Nelore were statistically similar during the three seasons; meanwhile, Brangus only had significant differences between the summer and fall (TABLE I and TABLE II). During the summer these findings might have been due to a voluntary decrease in feed consumption as a measure of adaptation to heat stress against extreme temperatures; while during the fall they may have been due to the lower nutritional value of the feed.

Lower nutritional value might have extended through the winter with differences that did not constitute significant findings, except in Brahman cows. Taking this hypothesis into account, the decrease in the intake of dry matter during the summer would set off events capable of negatively affecting the productivity of the herd. In that sense, Lamp et al. [13] reported a decrease in feed consumption by animals subjected to heat stress, along with an increase of urea and creatinine in blood. Increases in creatinine arose as a consequence of the degradation of tissue protein in order to ensure the provision of glucose from endogenous sources such as amino acids.

In order to verify this phenomenon, creatinine was simultaneously analyzed, which is a nitrogenated compound of non-protein origin commonly used in the determination of protein status, and as an indicator of renal function and muscle catabolism [4]. Both Nelore and Brangus surpass the reference range for creatinine (90 to 134 micromol $\left.(\mu \mathrm{mol}) \cdot \mathrm{L}^{-1}\right)$ in all three seasons and constituted significant findings when compared to the other genotypes (TABLE I). The local breeds Criollo Pilcomayo (94.37 $\left.\mu \mathrm{mol} \cdot \mathrm{L}^{-1}\right)$ and Ñeembucú (110.33 $\left.\mu \mathrm{mol} \cdot \mathrm{L}^{-1}\right)$ showed the lowest $(\mathrm{P}<0.05)$ concentrations during the summer; although during the fall, Brahman $\left(117.57 \mu \mathrm{mol} \cdot \mathrm{L}^{-1}\right)$ was statistically similar $(P>0.05)$ to them. During the winter, the level of creatinine was above the upper limit in the majority of the groups, except in Criollo Pilcomayo (120.39 $\left.\mu \mathrm{mol} \cdot \mathrm{L}^{-1}\right)$, which had a lower value that was statistically different $(P<0.05)$ from the other groups analyzed. Regarding Nelore, the creatinine levels may have been due to the mobilization of body reserves and muscle catabolism during the winter, which is consistent with the lowest and statistically significant $(P<0.05)$ scores for body condition (TABLE I and TABLE II).

Campos et al. [4] pointed out a tendency for increased levels of creatinine in subjects prone to undergoing metabolic changes in weight. It is possible to postulate greater functional compromise in Brangus and Nelore for an efficient performance under an extensive production system in wetlands, where animals must wander considerable distances in order to feed themselves adequately in terms of quality and quantity. This situation was not observed in the local breeds and Brahman, where the levels of creatinine revealed appropriate renal function without compromise of tissue protein as an endogenous energy source, particularly during the summer and fall.

Total serum protein was analyzed with the aim of estimating the capacity for synthesis, maintenance of oncotic pressure, humoral immunity, and substance transport [4]. All assessed genotypes presented values within the $66-90 \mathrm{~g} \cdot \mathrm{L}^{-1}$ range [27]; however, these values were higher than the ones published for local breeds raised under extensive farming systems as well as for dairy cows that were specialized for production under tropical conditions [3, 4]. The differences between genotypes were evident during the fall season in which Criollo Pilcomayo stood out with elevated levels of circulating serum protein (83.25 $\mathrm{g} \cdot \mathrm{L}^{-1}$ ) (TABLE I and TABLE II).

Considering this fact, the highest urea concentrations previously described for local breeds and in particular for Pilcomayo were not determined by an energy deficit; otherwise, protein synthesis would have been compromised concomitantly. The concentration of serum protein may be affected by the time of the yr, physiological state, and age. Low concentrations appear along with elevated levels of urea as a consequence of protein and energy deficiency in the diet during the negative energetic balance as is common postpartum and in early lactation, or under situations of caloric stress, or in young animals that have not yet finished their muscular development $[5,9,11]$.

This study dealt with adult animals, in similar physiological conditions and subjected to identical management practices, and Criollo Pilcomayo stood out by not showing fluctuations such as the ones observed in the other genotypes, which showed decreases during the fall in relation to the other seasons. It is important to consider that the decrease in some of the components analyzed in the protein $g$ may mask the increase of another, the total protein value still remaining constant [27]. Taking this into consideration, albumin was analyzed, since it constitutes $50-65 \%$ of the total serum protein. Albumin is synthesized by the liver and is the main long-term indicator of protein status $[1,10]$.

Wittwer [27] stated that concentrations outside the $26-41 \mathrm{~g} \cdot \mathrm{L}^{-1}$ interval are related to dysproteinemia. None of the genotypes showed concentrations below the critical level; on the contrary, during the winter, all groups registered values above the reference range. This is a finding with no apparent clinical usefulness, and is a situation that might have been due to a lower intake of liquids during the period resulting in hemo concentration.

Paradoxically, the differences detected between members of the zebuine group, Brahman and Nelore, reflected antagonistic behaviors in all three seasons assessed $(P<0.05)$ (TABLE I). In 
that regard, Alvarez [1] emphasized the influence of breed on the components of the total serum proteins, since it is common to observe elevated globulin levels in taurine cattle and of albumin in zebuine cattle. The difference in favor of the zebuines is linked to their ability to retain water as an adaptation measure in environments with higher temperature and humidity, a condition that in this study was made apparent in Brahman and its crosses (Brangus), and not in Nelore.

Albumin fluctuations can also be influenced by the nutritional quality of the feed and the physiological condition of the cows. Quintela et al. [21], detected important variations in the levels of albumin when assessing the Spanish local breed Rubia Gallega in different seasons, during the late pregnancy and early postpartum, with decreases associated with higher physiological demands. Their values were lower than the ones observed in this study; however, there was a correspondence with the lowest levels, recorded during the summer in comparison with the other seasons, both in Criollo Ñeembucú and in Nelore.

It is important to consider what was stated by some authors in previous studies $[12,20]$, they mentioned that a minimum of one mon is required in order to detect significant changes, since the speed of synthesis and degradation of albumin in ruminants is low. This is why the assessment of additional parameters such as body condition can provide further elements of analysis. In situations where the nutritional intake is compromised, either by a voluntary decrease in consumption during heat stress or because of a decline in the quality of the feed, as happens in the summer, it is to be expected that the animals resort to additional sources to ensure their energy supply. This includes fat mobilization, hepatic accumulation, and a reduction in the ability to synthesize albumin, a condition that will be accompanied by a lower score in body condition [5].

In view of this, while it is true that the albumin concentration detected in Nelore at the end of summer was not below the critical limit, it revealed a less favorable situation in contrast to the other genotypes, due to the low score for body condition, a value statistically different $(P<0.05)$ from the other groups.

Globulin is a protein associated with immune response reactions [1, 4]. The results differed between genotypes, with significant differences between Criollo Ñeembucú and Brahman during the summer and winter. During the fall, Criollo Pilcomayo (43.88 g. $\left.\cdot \mathrm{L}^{-1}\right)$ clearly stood out by showing the highest value (TABLE I). These findings relate to the influence of globulin on the higher concentrations of total serum protein previously mentioned for these breeds groups. All groups were within the $28-52 \mathrm{~g} \cdot \mathrm{L}^{-1}$ reference interval [27], as expected from clinically healthy animals. However, the higher globulin levels revealed the influx of a genetic factor in taurines, which might be a reflection of a greater capacity for immune response, especially against factors typical of the adverse conditions of the tropic [1, 4, 19, 23].

The albumin/globulin ratio detects possible imbalances, mainly in cases of hypoalbuminemia [19]. It was observed ratios within the range of 0.5 to 1.5 , mentioned by Wittwer [27] (TABLE I and TABLE II). Other studies carried out by Matheus et al. [16] and Watanabe et al. [26] verified ratios below 1.0 in local breeds, due to higher levels of the globulin fraction. Their results match the observations of this study, particularly during the summer, when the local breeds obtained values below 1.0, while Brangus and Brahman obtained higher values. Inconsistently, albeit a zebuine, Nelore did not surpass 1.0 in the same period, due to its low albumin levels.
The variation in nitrogenated compounds in the different genotypes was studied through the analysis of main components. For the summer, the analysis explained $66 \%$ of the total variation (FIG. 1).

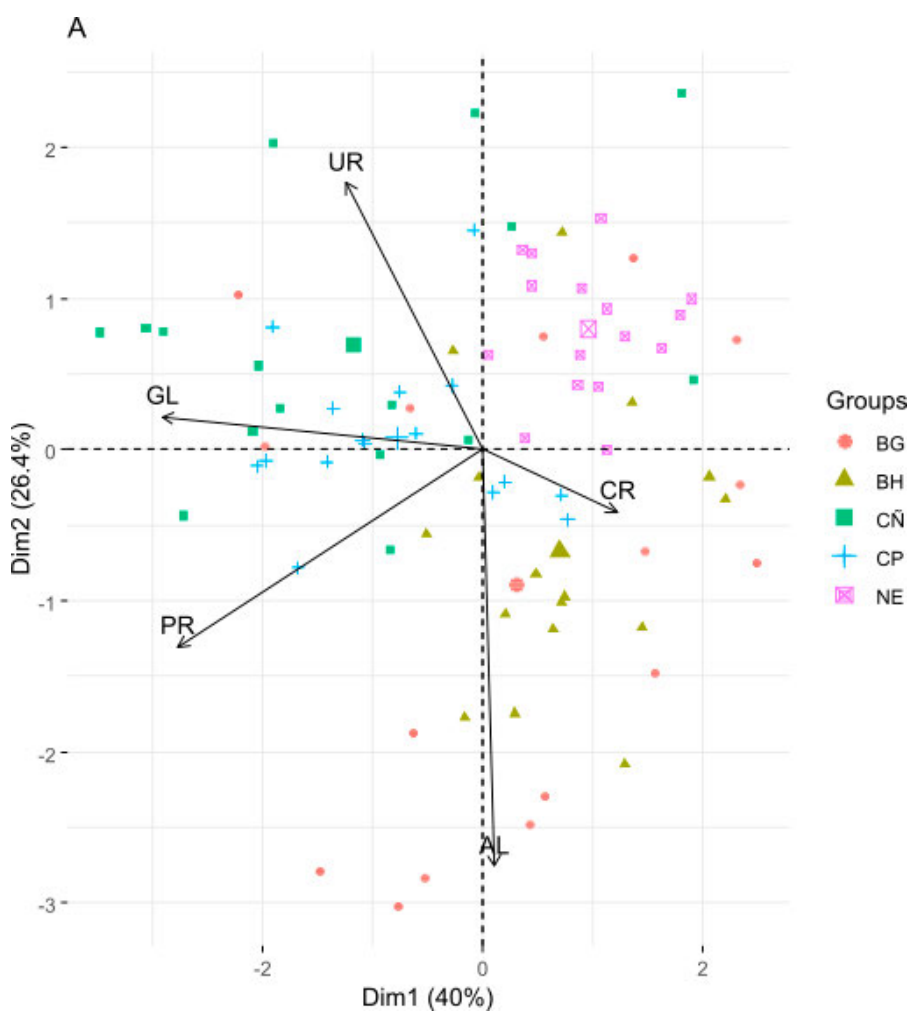

FIGURE 1. Analysis of the Main Components, in the Different Bovine Genotypes such as Albumin, Urea, Creatinine, Globulin and Total Proteins; Summer. BG: Brangus; BH: Brahman; CÑ : Criollo Ñeembucú; CP: Criollo Pilcomayo; NE: Nelore; UR: urea; GL: globulin; PR: total protein; CR: creatinine; AL: albumin

The first component was composed by urea, creatinine, globulin, and total protein, the latter two being the most strongly correlated to each other and having the greatest weight; while albumin was a part of the second component (TABLE III).

The projection of the results on the abscissa and ordinate axes identified Criollo Neembucú and Brahman as the most dissimilar. The local breeds showed elevated concentrations of globulin, total protein, and urea; while the exotic breeds showed greater concentrations of creatinine and albumin, with the exception of Nelore. The Nelore, along with the local breeds, stood out for low levels of albumin. For the fall, the explained variation was above $70 \%$ (FIG. 2).

The first component grouped globulin, total protein, albumin and creatinine, on whose projection Criollo Pilcomayo and Nelore were identified as the genotypes with the greatest inertia; the former with elevated levels of total protein and globulin, and the latter with higher concentrations of creatinine and albumin; a finding that was also seen in Criollo Neembucú. Urea, within the second 
TABLE III

Autovectors Corresponding to The First Two Main Selected Components in the Three Seasons Assessed

\begin{tabular}{cccc}
\hline Seasons & Variables & e1 & e2 \\
\hline \multirow{4}{*}{ Summer } & Urea $\left(\mathrm{mmol} \cdot \mathrm{L}^{-1}\right)$ & -0.28 & 0.50 \\
& Creatinine $\left(\mu \mathrm{mol} \cdot \mathrm{L}^{-1}\right)$ & 0.28 & -0.12 \\
& Total protein $\left(\mathrm{g} \cdot \mathrm{L}^{-1}\right)$ & -0.63 & -0.37 \\
& Albumin $\left(\mathrm{g} \cdot \mathrm{L}^{-1}\right)$ & 0.02 & -0.78 \\
& Globulin $\left(\mathrm{g} \cdot \mathrm{L}^{-1}\right)$ & -0.66 & 0.06 \\
\cline { 2 - 4 } & Urea $\left(\mathrm{mmol} \cdot \mathrm{L}^{-1}\right)$ & 0.13 & 0.64 \\
& Creatinine $\left(\mu \mathrm{mol} \cdot \mathrm{L}^{-1}\right)$ & 0.35 & 0.31 \\
& Total protein $\left(\mathrm{g} \cdot \mathrm{L}^{-1}\right)$ & -0.54 & 0.46 \\
& Albumin $\left(\mathrm{g} \cdot \mathrm{L}^{-1}\right)$ & 0.38 & 0.49 \\
& Globulin $\left(\mathrm{g} \cdot \mathrm{L}^{-1}\right)$ & -0.65 & 0.20 \\
\cline { 2 - 4 } Winter & Urea $\left(\mathrm{mmol} \cdot \mathrm{L}^{-1}\right)$ & -0.31 & 0.23 \\
& Creatinine $\left(\mu \mathrm{mol} \cdot \mathrm{L}^{-1}\right)$ & 0.03 & 0.26 \\
& Total protein $\left(\mathrm{g} \cdot \mathrm{L}^{-1}\right)$ & -0.65 & -0.34 \\
& Albumin $\left(\mathrm{g} \cdot \mathrm{L}^{-1}\right)$ & 0.14 & -0.87 \\
& Globulin $\left(\mathrm{g} \cdot \mathrm{L}^{-1}\right)$ & -0.68 & 0.05 \\
\hline
\end{tabular}

$\mathrm{mmol} \cdot \mathrm{L}^{-1}$ : millimole per liter; $\mu \mathrm{mol} \cdot \mathrm{L}^{-1}$ : micromole per liter; $\mathrm{g} \cdot \mathrm{L}^{-1}$ : gram per liter; $\mathrm{e} 1$ = autovector of component 1 ; $\mathrm{e} 2$ = autovector of component 2

component, discriminated the local breeds along with Nelore with higher blood levels, compared to the exotic breeds.

For the winter, $63 \%$ of the variation was explained. In this season the first component was reduced to urea, total protein and globulin, with higher coefficients in the latter two, contraposing the Criollo Ñeembucú and Brahman genotypes; on the other hand, the projections of creatinine and albumin on the $\mathrm{X}$-axis were close to zero and were a part of the second component. Nelore presented elevated levels of creatinine and low concentrations of albumin, contrary to Criollo Pilcomayo (FIG. 3).

These results are consistent with an interpretation that in less favorable periods, such as the summer and winter in the wetlands of Ñeembucú, Paraguay, the local breeds are capable of reorienting metabolic pathways linked to nitrogenated compounds.

This is a reflection of an adaptation process capable of optimizing the urea cycle by transforming ammonia and recycling the excess for protein synthesis, a process that improves efficiency and economy without compromising other endogenous sources for obtaining of energy [1]. The correlation and weight given to total protein and globulin when explaining total variation in each assessment period coincides with what was stated by Rodriguez-Valera et al. [23] in relation to the existence of genetic groups with features associated with particular functions of the immune system that were determined by specific genes in the natural selection process.

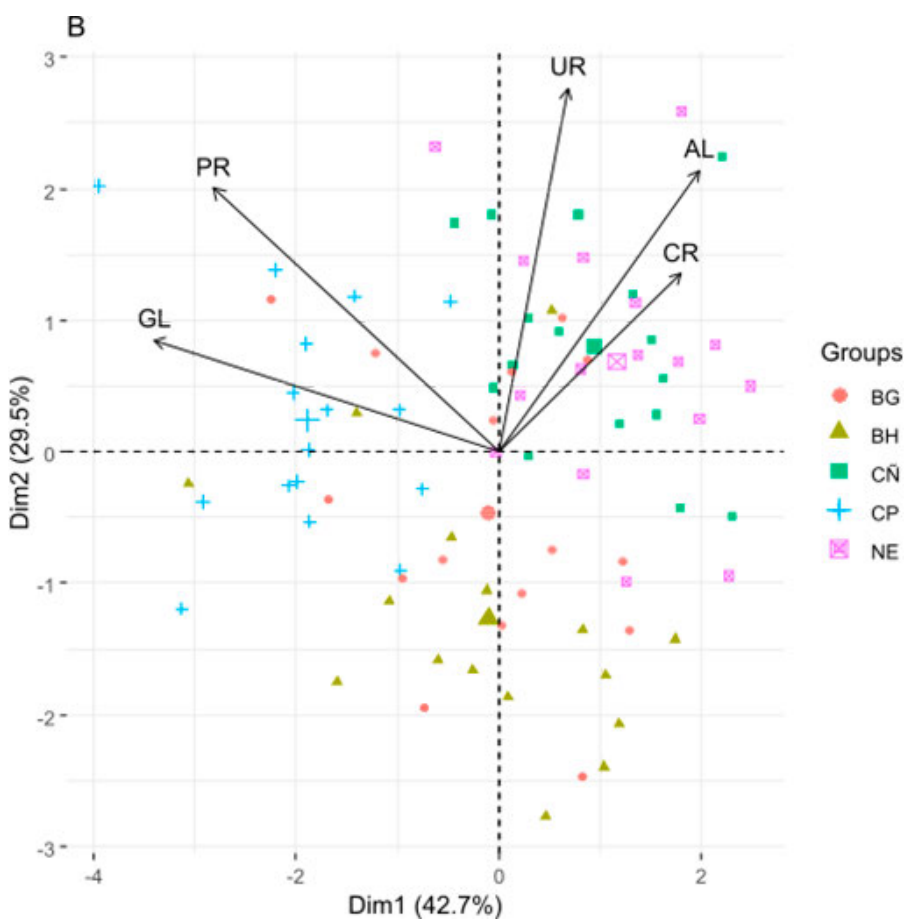

FIGURE 2. Analysis of the Main Components, in the Different Bovine Genotypes such as Albumin, Urea, Creatinine, Globulin and Total Proteins; Fall. BG: Brangus; BH: Brahman; CÑ: Criollo Ñeembucú; CP: Criollo Pilcomayo; NE: Nelore; UR: urea; GL: globulin; PR: total protein; CR: creatinine; AL: albumin

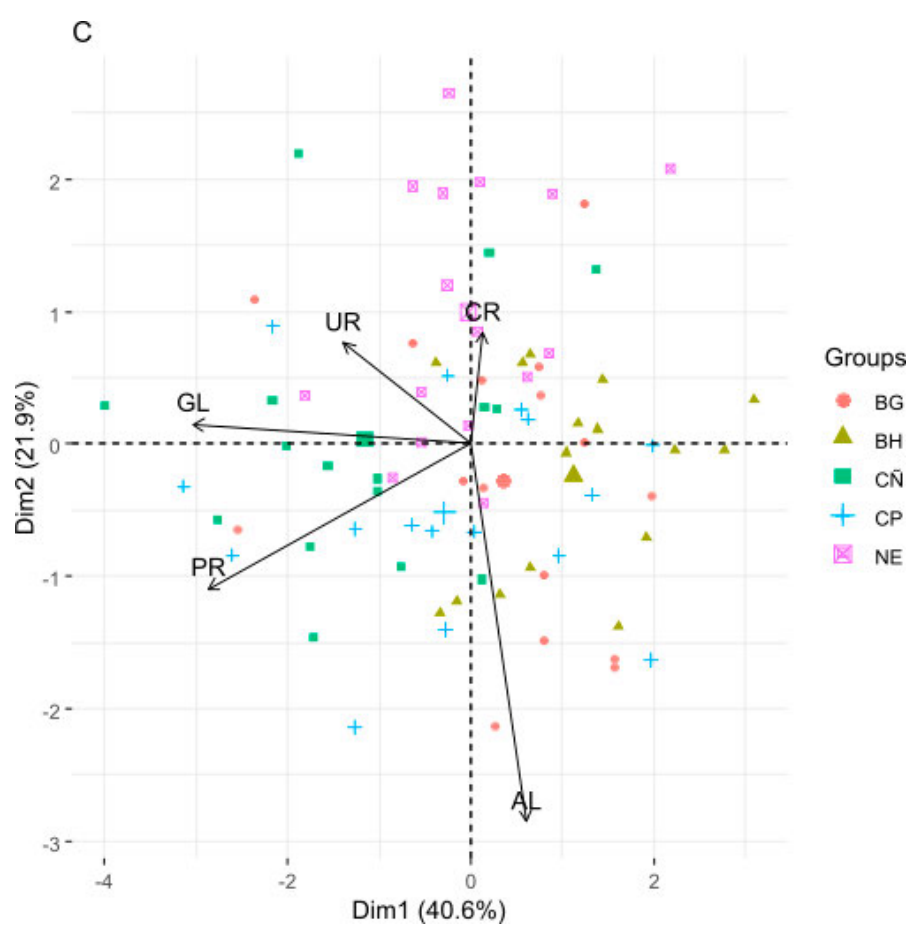

FIGURE 3. Analysis of the Main Components, in the Different Bovine Genotypes such as Albumin, Urea, Creatinine, Globulin and Total Proteins; Winter. BG: Brangus; BH: Brahman; CÑ: Criollo Ñeembucú; CP: Criollo Pilcomayo; NE: Nelore; UR: urea; GL: globulin; PR: total protein; CR: creatinine; AL: albumin 
Protein Status in Cattle raised in the Wetlands of Paraguay / Martínez-López et al.

\section{CONCLUSIONS}

In local cattle breed genotypes, elevated concentrations of urea in blood in combination with adequate levels of total serum protein can be associated with adaptation processes in the metabolic pathways of nitrogenated compounds.

Higher concentrations of globulin in blood in clinically healthy local breeds suggest an adequate capacity for immune response.

In exotic or foreign genotypes in unfavorable environments, a higher creatinine level is a potential indicator of the activation of mechanisms that compromise the integrity of the tissue protein and renal function.

\section{ACKOWLEGMENTS}

This research was funded by Paraguay's National Council of Science and Technology (CONACYT) through grant 14-INV-140 from the PROCIENCIA program, with resources from the Fund for the Excellence of Education and Research - FEEl.

\section{BIBLIOGRAPHIC REFERENCES}

[1] ALVAREZ, J. L. Nutrición. En: Bioquímica nutricional y metabólica del bovino en el trópico. 1a Ed. Universidad de Antioquia, Medellín. 201 pp. 2001.

[2] BARTRINA, L. Contexto geográfico general. En: Biodiversidad del Paraguay: una aproximación a sus realidades. SalasDueñas, D.; Facetti, J. (Eds.). Fundación Moisés Bertoni, Asunción, Pp 25-32. 2007.

[3] CAMPos, R; CARREÑO, E.S.; GONZÁleZ, F. D. Perfil metabólico de vacas nativas colombianas. Rev. Orinoquia. 8: 32-41. 2004

[4] CAMPOS, R.; CUBILLOS, C.; RODAS, A. G. Indicadores metabólicos en razas lecheras especializadas en condiciones tropicales en Colombia. Acta Agron. 56: 85-92. 2007.

[5] CONTRERAS, P. A.; PHIL, M.; VALENZUELA, L.; WITTWER, F.; BÖHMWALD, H., Desbalances metabólicos nutricionales más frecuentes en rebaños de pequeños productores de leche, Valdivia - Chile. Arch. Med. Vet. 28: 39-50. 1996.

[6] DARWIN, C. Interacción genotipo-entorno. En: El Origen de Las Especies. Centro Editor de Cultura, Buenos Aires. 416 pp. 2011.

[7] DE-GROOT, R. S.; STUIP, M. A. M.; FINLAYSON, C. M.; DAVIDSON, N. Valoración de humedales: Lineamientos para valorar los beneficios derivados de los servicios de los ecosistemas de humedales, Informe Técnico de Ramsar núm. 3/núm. 27 de la serie de publicaciones técnicas del CDB. 2007. Secretaría de la Convención de Ramsar. Suiza. Secretaría del Convenio sobre la Diversidad Biológica. Canadá. En Línea: https://bit.ly/3lHskBW. 09.07.2021

[8] EDMONSON, A. J.; LEAN, I. J.; WEAVER, L. D.; FARVER, T.; WEBSTER, G. A Body Condition Scoring Chart for Holstein Dairy Cows. J. Dairy Sci. 72: 68-78. 1989.

[9] GOMEZ-OQUENDO, J.; LONDOÑO, L. F.; PÉREZ, V. M. EI perfil metabólico como herramienta de monitoreo de la salud, la producción y la fertilidad en el hato lechero del Politécnico Colombiano. Rev. Lasallista Investig. 10: 38-50. 2013.
[10] GONZALEZ, F.; ORTOLANI, E.; CAMPOS, R.; SCHEFFER, J.; WITTWER, F.; CONTRERAS, P.; BÖHMWALD, H.; BARROS, L.; BOUDA, J.; QUIROZ-ROCHA, G. Indicadores metabólico. In: Doze leituras em bioquímica clínica veterinária. Faculdade de Veterinária, Universidade Federal do Rio Grande do Sul, Porto Alegre. 159 pp. 2018.

[11] KEKANA, T. W.; NHERERA-CHOKUDA, F. V.; MUYA, M. C.; MANYAMA, K. M.; LEHLOENYA, K. C. Milk production and blood metabolites of dairy cattle as influenced by thermalhumidity index. Trop. Anim. Health Prod. 50: 921-924. 2018.

[12] KIDA, K. Relationships of metabolic profiles to milk production and feeding in dairy cows. J. Vet. Med. Sci. 65(6): 671-677. 2003.

[13] LAMP, O.; DERNO, M.; OTTEN, W.; MIELENZ, M.; NÜRNBERG, G.; KUHLA, B. Metabolic Heat Stress Adaption in Transition Cows: Differences in Macronutrient Oxidation between LateGestating and Early-Lactating German Holstein Dairy Cows. PLoS ONE. 10: 1-24. 2015.

[14] MARTÍNEZ-LÓPEZ, R. Técnicas estadísticas. En: Métodos estadísticos aplicados en Zootecnia. 1a. Ed. Etigraf, Asunción. 292 pp. 2017.

[15] MARTÍNEZ-LÓPEZ, O. R.; PRAYONES, E.; ARRÚA, A.; OCHIPINTI, G.; GABAGLIO, J. M.; GODOY, E.; SERVÍN, G.; MARTÍNEZ-MARTÍNEZ, A.; DELGADO, J. V. Actividades de Conservación in situ y ex situ del ganado bovino Criollo Pilcomayo del Paraguay. XI Simposio Iberoamericano sobre conservación y utilización de Recursos Zoogenéticos. Joao Pessoa. 11/17-19. Brasil. Pp 523-526. 2010.

[16] MATHEUS, N.; RAMÍREZ, F.; SALAZAR, C.; LEONARDI, F.; BRAVO, H. Relación albúmina:globulina plasmáticas en tres épocas del año en vacas de la raza Carora del estado Lara, Venezuela. Gac. Cs. Vet. 7: 4-10. 2001.

[17] NAHED-TORAL, J.; PALMA-GARCÍA, J. M.; GONZÁLEZGARCÍA, E. The adaptive capacities as a key feature in the promotion of resilient animal production systems. Rev. AIA. 18: 7-34. 2014.

[18] NORO, M.; BORKERT, J.; HINOSTROZA, G. A.; PULIDO, R.; WITTWER, F. Variaciones diarias de metabolitos sanguíneos y su relación con el comportamiento alimenticio en vacas lecheras a pastoreo primaveral. Rev. Científ. FCV-LUZ. XXI (2): 125-130. 2011.

[19] OLIVEIRA, R. S. B. R.; MOURA, A. R. F.; PÁDUA, M. F. S.; BARBON, I. M.; SILVA, M. E. M.; SANTOS, R. M.; MUNDIM, A. V.; SAUT, J. P. E. Perfil metabólico de vacas mestiças leiteiras com baixo escore de condição corporal no periparto. Pesqui. Vet. Bras. 34: 362-368. 2014.

[20] PEIXOTO, L. A. de O.; BRONDANI, I. L.; NÖRNBERG, J. L.; RESTLE, J.; ALVES-FILHO, D. C.; PAZINI, M.; CORADINI, M. T.; dos SANTOS, C. V. M. Perfil metabólico protéico e taxas de concepção de vacas de corte mantidas em pastagem natural ou suplementadas com farelo de trigo com ou sem uréia. Cien. Rural. 36 (6): 1873-1877. 2006.

[21] QUINTELA, L. A.; BECERRA, J. J.; REY, C.; DIAZ, C.; CAINZOS, J.; RIVAS, F.; HUANCA, W.; PRIETO, A.; HERRADÓN, P. G. Perfiles metabólicos en preparto, parto y posparto en vacas 
de raza rubia gallega: estudio preliminar. Recur. Rurais. 7: 5-14. 2011.

[22] R CORE TEAM. R: A language and environment for statistical computing. 2020. R Foundation for Statistical Computing, Vienna, Austria. On Line: https://www.R-project.org/. 01.08.20

[23] RODRIGUEZ-VALERA, Y;; RENAND, G.; NAVES, M.; FONSECAJIMÉNEZ, Y.; MORENO-PROBANCE, T. I.; RAMOS-ONSINS, S.; ROCHA, D.; RAMAYO-CALDAS, Y. Genetic diversity and selection signatures of the beef 'Charolais de Cuba' breed. Sci. Rep. 8: 1-9. 2018.

[24] SECRETARÍA DE LA CONVENCIÓN DE RAMSAR. La Lista de Humedales de Importancia Internacional. 2021. Secretaría de la Convención de Ramsar. Suiza. En Línea: https://bit. ly/3pFkfoA. 09.07.2021

[25] VÉLIZ-CAPUÑAY, C. Componentes principales. En: Análisis Multivariante: métodos estadísticos multivariantes para la investigación. 1a Ed. Cengage Learning, Buenos Aires. 196 pp. 2016.
[26] WATANABE, U.; TAKAGI, M.; YAMATO, O.; OTOI, T.; TSHERING, C.; OKAMOTO, K. Metabolic Profile of Japanese Black Breeding Cattle Herds: Usefulness in Selection for Nutrient Supplementation to Enhance Reproductive Performance and Regional Differences. J. Vet. Med. Sci. 75: 481-487. 2013.

[27] WITTWER, F. Medicina Veterinaria. En: Manual de Patología Clínica Veterinaria. 2a Ed. Imprenta América, Valdivia. 200 pp. 2012.

[28] WITTWER, F.; BÖHMWALD, H.; CONTRERAS, P. A.; PHIL, M.; FILOZA, J. Análisis de los resultados de perfiles metabólicos obtenidos en rebaños lecheros en Chile. Arch. Med. Vet. 19: 35-45. 1987.

[29] WITTWER, F.; REYES, J. M.; OPITZ, H.; CONTRERAS, P. A.; PHIL, M.; BÖHMWALD, H. Determinación de urea en muestras de leche de rebaños bovinos para el diagnóstico de desbalance nutricional. Arch. Med. Vet. 25: 165-172. 1993. 
